PRZEGLĄD RUSYCYSTYCZNY 2021, $\mathrm{nr} 4$ (176)

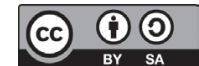

DOI 10.31261/pr.9154

\title{
ТАТЬЯНА КОСМЕДА
}

Донецкий национальный университет имени Василия Стуса в Виннице, Украина

(D) 0RCID: https://orcid.org/oooo-0001-8912-2888

\section{ФЕМИННАЯ МЕТАФОРА В ЯЗЫКЕ \\ СОВРЕМЕННЫХ РУССКО- И УКРАИНСКОЯЗЫЧНЫХ ГАЗЕТ (НА ПРИМЕРЕ МОДЕЛИРОВАНИЯ МЕДИАОБРАЗА ЮЛИИ ТИМОШЕНКО)}

\author{
FEMINE METAPHOR IN MODERN RUSSIAN AND UKRAINIAN-LANGUAGES NEWSPAPERS \\ (BASED ON THE EXAMPLE OF YULIYA TYMOSHENKO'S MEDIA IMAGE MODELLING)
}

\begin{abstract}
The newspaper discourse captures the active language processes, consistently reflects the sequence of events which take place in the society, provides the possibilities for modeling the media image of the political leaders, in particular, the woman politician Yuliya Tymoshenko, while demonstrating the ample opportunities in order to create the metaphors, the periphrases, the language games based on the precedence actualization and the anthroponym systems taking into consideration the gender principles — the androcentrism, the sexism and the femininity.

Keywords: newspaper discourse, feminine metaphor, ornamental means, media image, image of a politician
\end{abstract}

Метафора - «приговор суда без разбирательства» ${ }^{1}$

\section{ВВЕДЕНИЕ}

Газету образно называют «летописью современности». Конец XX - начало XXI веков, без сомнения, характеризуются активным развитием массовой коммуникации.

Динамическое развитие традиционных СМИ: печати, радио, телевидения, появление новых компьютерных информационных технологий, глобализация мирового информационного пространства оказывают огром-

${ }^{1}$ Н. Д. Арутюнова, Метафора и дискурс // Н. Д. Арутюнова, М. А. Журинская (ред.), Теория метафоры, Прогресс, Москва 1990, с. 28. 
ное влияние на производство и распространение слова. Все эти сложные и многократные процессы требуют не только научного осмысления, но и разработки новых парадигм практического исследования языка СМИ².

Речь идет о публицистическом стиле, который обслуживает СМИ. Сегодня именно публицистический стиль фиксирует те основные активные процессы, изменения, которые характерны для каждого отдельного языка. Газетный дискурс ориентируется на «живую» речь, влияет на формирование языкового сознания читателей и отражает языковое мышление журналистов, их лингвокреативность. Задача журналистов - сделать этот дискурс выразительным, ярким, убедительным, понятным и привлекательным. К основным образным средствам газетной речи относится метафора, постоянно обновляющаяся и модернизирующаяся, поэтому газетный дискурс требует пристального внимания и систематического изучения.

Подчеркнем, что особое внимание журналистов привлекает образ политических лидеров. Образ, в частности и метафорический, политического деятеля формируется на основании дискурса этого политика, его поведения, в частности и коммуникативного, вербальных характеристик, которыми его "награждают» журналисты, оценивающие его деятельность, принимаемые им решения, а также факты биографии ${ }^{3}$, что, прежде всего, связано с его антропонимными характеристиками. Создаются так называемые медиаобразы политических лидеров, среди которых особое внимание привлекают образы феминные. Все сказанное мотивирует актуальность темы настоящего разыскания. Объектом этой статьи является метафора, функционирующая в языке современных русско- и украинскоязычных газет, а ее предметом - феминная метафора, т.е. метафора, вербализующая антропонимикон женщины-политика Юлии Тимошенко, создавая ее медиаобраз. Подчеркнем, что именно антропонимы, имена политиков - «важнейшие ориентационные знаки политического дискурса, знаки с необычайной информативной емкостью» ${ }^{4}$ безусловно:

${ }^{2}$ Т.Г. Добросклонская, Медиалингвистика: системный подход к изучению языка СМИ: современная английская медиасеть. Флинта, Москва 1999, с. 5 .

${ }^{3}$ Е. Г. Белявская, Фрейм «политик» в англоязычном биографическом дискурсе (к методике анализа), «Политическая лингвистика» 2012, № 40 (2), с. 12.

${ }_{4}^{4}$ А.А. Романова, Е.Г. Романова, Н.Ю. Воеводкин, Имя собственное в политике: язык власти и власть языка. Лилия ЛТД, Москва 200о, с. 22. 
имя собственное, вплетенное в прагматический контекст его использования, является своеобразным «сигналом личности» (термин Макса Лющера), способным формировать имидж носителя этого имени или номинанта как добрую, активную, симпатичную, бесконфликтную, деятельную личность. Точно также оно способно участвовать в формировании прямо противоположного образа номинанта этого имени собственного 5.

Последнее наблюдаем чаще, ибо общеизвестно, что современная языковая личность ориентирована на порождение негативных смыслов. Ученые объясняют это природой человеческой психики. Поэтому не вызывает сомнения, что в каждом языке больше слов, выражающих пейоративные значения, негативные смыслы6 ${ }^{6}$ Лингвисты убеждены, что

речевая метафора в СМИ нередко служит средством экспрессивного, а значит, наиболее действенного выражения оценочного содержания, причем чаще негативного, что объясняется повышенным вниманием СМИ к неблагополучным сторонам общественной действительности, разноаспектной человеческой деятельностью. И это вполне понятно: задача СМИ - способствовать улучшению жизни общества, вскрывая имеющиеся недостатки. В условиях, когда выражение отрицательной оценки становится самоцелью автора, метафора может придать тексту то, что мы называем речевой агрессией ${ }^{7}$.

Исследовательский материал этой статьи - современные русско- и украинскоязычные газеты, в частности: «Антифашист» (А), «Вся правда» (ВП), «Диалог» (Д), «День», «Новое время» (HB), «RYBALTIC.py» (PЫ), «Федеральное агентство новостей» (ФАН), «Царьград» (Ц), а также «Дзеркало тижня» (ДТ), «Слово просвіти» (СП), «Україна молода» (УМ), «Літературна Україна» (ЛУ). Выбор перечисленных газет мотивирован тем, что их принято считать наиболее авторитетными и популярными. В частности, Академия украинской прессы провела в 2019 году исследование, позволившее определить, какие из газет больше всего влияют на социальную и политическую активность граждан. Большая часть газет, используемых в качестве исследовательской базы в этой статье, находится в этом рейтинге (на первом месте - «Дзеркало тижня», далее следуют «День»,

5 Там же, с. 80.

${ }^{6}$ Подробнее см. об этом: Т. Космеда, Аксіологічні аспекти прагмалінгвістики: формування і розвиток категорї̈ оцінки, ЛНУ ім. І. Франка, Львів 2000.

${ }^{7}$ Н. Е. Петрова, Л. В. Рацибурская, Язык современных СМИ: средства речевой агрессии. Флинта: Наука, Москва 2011, с. 92. 
«Україна молода», «Літературна Україна»). Этот рейтинг «выведен» на основании мнения экспертов - ученых, преподавателей, медиа-аналитиков, журналистов, редакторов изданий, представителей организаций, связанных с медиа, и т.д.. ${ }^{8}$ Ряд российских и иностранных изданий называют «Федеральное агентство новостей» ${ }^{9}$ и «Царьград» ${ }^{10}$ самыми крупным изданиями в «фабрике медиа». Примеры из перечисленных изданий были собраны методом сплошной выборки. Среди иллюстративного материала имеются заголовки, выражающие «основной замысел, идею текста» и всегда находящиеся «в сильной позиции по отношению к тексту» ${ }^{11}$, они выполняют "роль крючка, заглотнув который, читатель знакомится со своим 'уловом' - всей публикацией»12, но подобных примеров в авторской картотеке немного - всего 5. Преимущественно имеем дело с текстовыми употреблениями - более 120-ти примеров, из которых более 60ти репрезентируют одинаковые метафорические образования. Иллюстративный материал очерчивает период с 2001 по 2018 годы - различные этапы деятельности Юлии Тимошенко, отличающиеся разной ее активностью, разными выполняемыми ею функциями, что и позволяет ввести в картотеку неординарные примеры. Для данного разыскания отобраны наиболее яркие примеры, иллюстрирующие разные механизмы образования метафоры с аппликацией других образных средств. Процесс метафоризации антропонимов в СМИ на материале русского, украинского, польского, немецкого и английского языков рассматривался в научных исследованиях Людмилы Артемовой ${ }^{13}$,

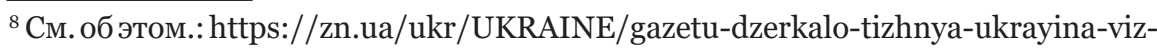
nano-liderom-populyarnosti-sered-mediaekspertiv-136294.html (30.05.2019).

9 См. об этом.: https://ru.wikipedia.org/wiki/\%Do\%A4\%Do\%B5\%Do\%B4\%Do \%B5\%D1\%80\%Do\%Bo\%Do\%BB\%D1\%8C\%Do\%BD\%Do\%BE\%Do\%B5_\%Do \%Bo\%Do\%B3\%Do\%B5\%Do\%BD\%D1\%82\%D1\%81\%D1\%82\%Do\%B2\%Do\%B E_\%Do\%BD\%Do\%BE\%Do\%B2\%Do\%BE\%D1\%81\%D1\%82\%Do\%B5\%Do\%B9 (20.09.2019).

${ }^{10}$ Cм. об этом.: https://ru.wikipedia.org/wiki/\%Do\%A6\%Do\%Bo\%D1\%80\%D1\%8 C\%Do\%B3\%D1\%80\%Do\%Bo\%Do\%B4_\%Do\%A2\%Do\%92 (20.09.2019).

${ }^{11}$ А.А. Лютая, Современный газетный заголовок: структура, семантика, прагматика: автореф. дис. ... канд. филол. наук., Волгоград 2008, с. 19.

${ }^{12}$ С. М. Гуревич, Номер газеты, Аспект Пресс, Москва 2002, с. 46.

${ }^{13}$ Л.А. Артемова, Особенности функционирования антропонимов в немецких медийных текстах, http://www.dissercat.com/content/osobennosti-funktsionirovaniya-antroponimov-v-nemetskikh-mediinykh-tekstakh\#ixzz2u9EVcH8o (15.02.2018). 
Татьяны Космеды ${ }^{14}$, Инны Пироги и Ларисы Изотовой ${ }^{15}$, Ольги Пономаревой ${ }^{16}$, Мариуша Рутковского ${ }^{17}$, Чеслава Кошиля ${ }^{18}$ и др.

Цель статьи - показать информативно-выразительный потенциал феминной метафоры, основанной на манипуляции антропонимами, называющими женщину-политика Юлию Тимошенко, что находит выражение в русско- и украинскоязычном газетном дискурсе, создавая ее медиаобраз. Русско- и украинскоязычный газетный дискурс избран по той причине, что именно в украинской и русской лингвокультуре образ популярного политика Юлии Тимошенко находится в центре внимание около 20 лет и поэтому этот феминный антропоним довольно активно подвергается метафоризации. В газетных текстах других языков данный антропоним употребляется преимущественно в информационных жанрах в прямом значении.

\section{ПОНЯТИЕ ФЕМИННОСТИ И ФЕМИННОЙ МЕТАФОРЫ}

Гендер активно вошел в науку в последнее десятилетие XX века. Лингвисты подчеркивают, что «новое понимание действительности, переоценка ценностей, пробудившийся интерес к частной жизни человека, развитие новых теорий личности привели к пересмотру научных принципов изучения категорий

14 Т.А. Космеда, Метафора сучасної публіцистики: актуалізація антропонімів (на матеріалі української та російської мов). «Науковий вісник ДДПУ імені І. Франка». Серія «Філологічні науки». Мовознавство 2015, № 3, с. $106-122$.

${ }^{15}$ I. І. Пірога, Л. І. Ізотова, Метафора як засіб створення іміджу політичного лідера в німецькомовному медіадискурсі, «Дискурсологія, семантика і прагматика. Вісник ХНУ ім. В. Н. Каразіна. Іноземна філологія» 2018, вип. 88, c. $35-42$.

${ }^{16}$ О.А. Пономарева, Вербализация политического имиджа в российских и американских средствах массовой информации: дис. ... канд. филол. наук, Волгоград, 2008.

17 M. Rutkowski, Nazwy wlasne $w$ strukturze metafory $i$ metonimii. Proces deonimizacji, «Onomastica» 2017, LXI/2, c. 91-104; M. Rutkowski, Koncepcja opisu konotacjinazwwtasnych w Stownikumetafor i konotacjinazw. «Poznańskie Studia Polonistyczne. Seria Językoznawstwo» 2012, т. 19 (39), № 1, c. 141-148.

${ }^{18} \mathrm{Cz}$. Kosyl, Metaforyczne użycie nazw wtasnych // M. Szymczak (ред.), Z zagadnień współczesnegojęzyka polskiego, Ossolineum, Wrocław-Warszawa-KrakówGdańsk 1978. 
этничность, возраст и пол» ${ }^{19}$. Лингвистические гендерные исследования, как известно, сосредотачивались на описании всего того, что касается норм, значений и стереотипов, связанных с дихотомией женщина-мужчина. Но сегодня проблематика гендерной лингвистики проектируется на изучение разнообразных обычаев, норм поведения, а также специфики социализации мужчин и женщин, вербализации всего, что с этим связано. Проблематика гендерной лингвистики, как известно, широка. В основном эта наука занимается решением таких вопросов, как особенности речевого поведения мужчин (маскулинность речи) и женщин (феминность речи), анализ номинаций, связанных с деятельностью мужчин или женщин, наличие родовых противоположностей, характеризующих определенный пол и др. Язык, что общеизвестно, последовательно отражает принцип андроцентризма: «это не просто взгляд на мир с мужской точки зрения, а выдача мужских нормативных представлений и жизненных моделей за единые универсальные социальные нормы и жизненные модели» ${ }^{20}$. На этом принципе базируются и метафоры языка газеты, т.к. язык, который мы используем в общении, создает картину мира, учитывая, прежде всего, мужскую точку зрения, мужское мировидение, что отражается и при моделировании «женских» метафор ${ }^{21}$. Однако сегодня наблюдается высокая актуализация феминности, т.е. нормативного представления о соматических, психических и поведенческих свойствах, характерных для женщин; это характеристика, связанная с женским полом, определенными формами поведения, ожидаемыми от женщины в обществе, что, соответственно, вербализируется. Считается, что феминность обусловлена биологически, а женщине лишь приписывались такие черты, как пассивность, отзывчивость, мягкость, поглощенность материнством, эмоциональность и т.п. Эти представления мотивированы соотнесенностью женщин с частной, а не публичной сферой

${ }_{19}$ В.М. Войченко, Отражение гендерных стереотипов в языке и культуре, «Вестник Волгоградского государственного университета», серия Языкознание, 2009, № 1 (9), с. 64.

${ }^{20}$ А. А. Денисова (ред.), Словарь гендерных терминов, Информация XXI века, Москва 2002, с. 4.

${ }^{21}$ См. об этом подробнее: Т.А. Космеда, Н.А. Карпенко, Т.Ф. Осіпова, Л. М. Саліонович, О. В.Халіман, Гендерна лінгвістика в Украӥні: історія, теоретичні засади, дискурсивна практика. ХНПУ ім. Г. С. Сковороди, Коло, ДрогобичХарків 2014. 
жизни. Тем не менее, преобладает точка зрения, что феминность не столь связана с биологией, ибо она конструируется на основе поведения женщин в социуме: с детства девочка подвергается осуждению, если она недостаточно женственна. По мнению французских феминистских теоретиков, в частности Элен Сиксу и Юлии Кристевой, фемининность - произвольная категория, которой женщин наделил патриархат ${ }^{22}$, что выражается в сексизме, в том числе и языковом, о чем подробно пишет Алла Архангельская ${ }^{23}$.

Феминности, естественно, противопоставляют маскулинность, но маскулинные черты (стойкость, мужественность, самодостаточность, смелость и др.) важны для всех - и мужчин, и женщин, а феминные (нежность, эмоциональность, ласковость, уязвимость, умение подчиняться воле мужчин и др.) - свойственны преимущественно женщинам, в частности и с точки зрения их привлекательности для мужчин. Сущность феминности усматривают в установлении для женщин ограничений, которые в конечном итоге именно мужчины находят необходимыми, полезными и приятными для себя.

Начиная с 70-х гг. XX века, женщины отвергли феминность как черту, воспроизводящую их вторичный статус (сделаны из ребра мужчины) в пользу маскулинности. Однако считается, что такие черты феминности, как эмоциональность, уязвимость и интуиция - это не слабость, а особая сила, которая чрезвычайно нужна социуму. Феминность развивается в связи с распространением феминизма как социального явления, связанного с повышением роли женщины в обществе. Она, безусловно, фиксируется в языковых формах, языковой картине мира, вторичных, образных наименованиях, которые попытаемся проследить на материале феминных номинаций, имеющих место в языке современных русско- и украискоязычных газет и активно в них функционирующих. В языке газеты, как уже отмечалось, распространена метафора, базирующаяся на имени собственном женщин - известных политических деятелей.

${ }^{22}$ См.: Словарь гендерных терминов, А. А. Денисова (ред.). Информация XXI века, Москва 2002, с. 191.

${ }^{23}$ А. Архангельская, Сексизм в языке: мифы и реальность. Univerzita Palackého, Olomouc 2011. 


\section{СОВРЕМЕННАЯ ЛИНГВИСТИЧЕСКАЯ ИНТЕРПРЕТАЦИЯ МЕТАФОРЫ}

До середины XX века метафора рассматривалась исключительно как эмоционально-эстетическое средство воздействия на человека, его мировоззрение, психологическое восприятие действительности. Современными «отцами-исследователями» метафоры принято считать Джона Лакоффа и Майкла Джонсона, показавших метафору в совершенно новом когнитивном ключе. Когнитивная наука о метафоре убеждает, что она является неотъемлемой частью человеческого мышления, ибо при помощи метафоры человек создает мир, в котором он живет ${ }^{24}$.

Длительное время в науке доминировал субстанциональный подход к исследованию метафоры. Это значит, что метафору понимали, как скрытое сравнение, которое можно употребить и в буквальном смысле. Но в последнее время более популярным становится интеракционистский подход, в соответствии с которым метафора - это не сравнение, а последовательность мыслей, ассоциаций, связанных между собой, проникающих друг в друга, что в результате и порождает новый смысл ${ }^{25}$.

Татьяна Ещенко указала на способы определения метафоры одним ключевым словом, ср.: «коренная» (Стивен Пеппер), «базисная» (Эрл МакКормак), «ориентационная», «онтологическая» (Джон Лакофф и Майкл Джонсон), «магическая» (Рене Веллек, Элизабет Воррен), «терапевтическая» (Дэвид Гордон) и др. ${ }^{26}$. И этот ряд можно продолжить. Активное изучение метафоры в конце XX века привело к фо р м и р о ва н и ю м ет а ф о р о л о г и и как самостоятельного научного лингвистического направления, требующего дальнейшей разработки.

Метафора, как известно, представляет собой способ сохранения и передачи от поколения к поколению ассоциаций, стереотипов, эталонов национально-культурной общности. В соответствии с этим метафоры базируются на системе общепринятых аналогий, ассоциаций, усвоенных в процессе социализации

${ }^{24}$ См. об этом: Е. В. Ковалевская, Метафора и сравнение в публицистическом тексте, «Вестник КГУ им. Н. А. Некрасова» 2009, № 3, с. 80.

${ }_{25}$ См.: Е. Ю. Сафронова, Индивидуальные смыслы метафоры, «Вестник Алтайского государственного аграрного университета» 2006, № 3.

${ }^{26}$ См.: Т. Єщенко, Текстово-антропоцентричний вимір метафори украӥнських поетів 1990-х, Академвидав, Київ 2018, с. 4. 
и овладения родным языком. Процесс создания метафоры связан с (а) концептуальной системой носителей языка, (б) их стандартными представлениями о мире, (в) существующей системой оценок. Безусловно, самым важным компонентом механизма метафоризации является процедура сравнения (Нина Арутюнова, Эрик МакКормак). Метафора предполагает наличие тождества между свойствами ее семантических референтов, поскольку она должна быть понятной; метафора призвана создавать новый смысл, т.е. владеть суггестивностью. Метафора - это видение одного предмета сквозь другой предмет. После «прагматического переворота» в лингвистике в 60-70 годы XX века появляется «стандартная прагматическая модель метафоры» (Пол Грайс, Джон Серль), в соответствии с которой последняя возникает благодаря интенциям говорящего и зависит от них. В современном критическом анализе дискурса (Рут Водак, Тен ван Дейк) и коммуникативной лингвистике метафора квалифицируется как средство коммуникативного влияния, поэтому и направляет исследовательские усилия не на определение и обоснование метафор, а на оценку их использования как способа манипуляции сознанием, что особенно проявляется в газетном дискурсе.

Создание и понимание метафоры - это результат творческих усилий: нет инструкций для определения того, что метафора означает. Ни одна теория метафорического значения не в состоянии объяснить, как функционирует метафора, от каких факторов и в какой степени зависит ее коннотативный диапазон и смысловая выразительность, что и создает самую большую методологическую сложность оперирования метафорой. Исследуя м еханиз мы ме тафори заци и, лингвисты считают, что не обязательно искать общие схемы, свойственные словарным определениям. Речь идет об общих ассоциациях, зачастую трудно определяемых ${ }^{27}$. В связи со сказанным Дональд Дэвидсон предлагает такое образное, но размытое определение метафоры: «это мир сновидений (dreamwork of language)» ${ }^{28}$. Важным, по мнению Дэвидсона, является не значение метафоры, а ее употребление, поскольку именно в процессе функционирования метафора раскрывает свою главную эстетическую особенность.

${ }_{27}^{27}$ В.Г. Гак, Языковые преобразования, Школа «Языки русской культуры», Москва 1988, с. 484.

${ }^{28}$ Д. Дэвидсон, Что означают метафоры // Н. Д. Арутюнова, М. А. Журинская (ред.), Теория метафоры, Прогресс, Москва 1990, с. 173. 
Исследователи справедливо отмечают, что «каждая культурно-историческая эпоха, стиль искусства вырабатывают свой способ художественно-образного осмысления мира, собственную метафорику, которая в пределах универсальности имеет особенности и неповторные черты» ${ }^{29}$.

Метафора, как отмечалось, часто сочетается с другими тропами и, прежде всего, с перифразой. Перифразы, как и метафора, обязательно передают определенный тип оценки, поскольку «они никогда не становятся обыкновенными лексическими параллелями существующих номинаций» ${ }^{30}$. Механизм образования перифразы, как известно, объясняется тем, что происходит переименование предмета или явления. Это новое название используют вместо первичного, т.е. вместо основного названия, в частности и имени собственного ${ }^{31}$. В качестве перифраз часто выступают другие имена собственные, обладающие характерными признаками. Так может моделироваться и языковая игра прием создания комического эффекта вследствие манипуляции образными средствами ${ }^{32}$. В собранных в этой статье примерах много таких, которые базируются именно на сочетании метафоры и перифразы, что и создает яркие оценочные медиаобразы, иногда с ироническим оттенком. Ирония, естественно, создает ощущение, что предмет обсуждения не таков, каким он кажется.

В основе метафоры и иронии лежат принципиально разные когнитивные механизмы. В то время как метафора становится возможной благодаря нахождению общих свойств двух объектов, ирония основана на когнитивном диссонансе между содержанием высказывания и реальным положением дел ${ }^{33}$

29 Л.О. Андрієнко, Генеза та особливості структури метафори бароко: дис.... канд. філол. наук, Київ 1997.

${ }^{30}$ М.П. Коломієць, Є. С. Регушувський, Короткий словник перифраз. Радянська школа, Київ 1985, с. 3.

${ }^{31}$ См. подробнее: M. Bańko, Peryfrazy w naszym życiu, «Poradnik Językowy» 2002, № 9; E. Straś, Peryfrazy $w$ środkach masowego przekazu (na materiale prasy polskiej i rosyjskiej) // P. Czerwiński (red.), Konfrontacje języków stowiańskich na poziomie leksyki, stowotwórstwa i składni, Wydawnictwo Uniwersytetu Śląskiego, Katowice 2001.

${ }^{32}$ См. об этом: Т.А. Космеда, О.В. Халіман, Мовна гра в парадигмі інтерпретативної лінгвістики. Граматика оцінки. Граматична ігрема (теоретичне осмислення дискурсивної практики), Коло, Дрогобич 2013.

${ }^{33}$ К. М. Шилихина, Метафора и ирония, «Вестник Воронежского государственного университета. Серия Лингвистика и межкультурная коммуникация» 2009, № 2, c. 40. 
Наиболее популярным механизмом образования метафоры в языке современной газеты является актуализация прецедентности. Прецедентный феномен - явление, базирующееся на интеллектуально-эмоциональной памяти определенного национально-лингвального сообщества. Актуализация прецедентности «заставляет» читателя глубже анализировать текст, создавая в сознании реципиента цепочку определенных ассоциаций. Прецедентность активизирует человеческое мышление и способствует моделированию оригинальных образных средств, в том числе и метафор. В качестве прецедентных феноменов часто выступают имена собственные.

\section{ОСОБЕННОСТИ МЕТАФОРИЗАЦИИ АНТРОПОНИМА ЮЛИЯ ТИМОШЕНКО}

Анализ собранного материала показывает, что, как подчеркивалось, в нем преобладает моделирование пейоративных смыслов, вербализируется преимущественно негативная оценка, что покажем на примерах медиаобраза известного украинского политика Юлии Тимошенко.

Прежде всего, негативно оценивается ее политическая деятельность, факты биографии, ср.: рус. ретроград, «газовая принцесса» (Граждане Украины готовы проголосовать за «газовую принцессу», потому что она ретроград [Ц, 21.01.2018]); рус. агент Кремля ([...] Тимошенко включили в санкционные списки исключительно для того, чтобы ее не считали агентом Кремля [Ц, 02.11.2018]); рус. канцлер нации (Новый канцлер нации: фрау Капительман-Тимошенко [ВП, 19.06.2018]). В последнем примере негативный образ создается и за счет актуализации девичьей фамилии Юлии Тимошенко - Капительман: эта фамилия - маркер еврейской национальности, иногда оцениваемой в обществе неодобрительно. Пейоративная коннотация создается и при помощи актуализации сведений о социальном статусе женщины-политика, указанием на ее пенсионный возраст и, соответственно, о невозможности осуществлять активную политическую деятельность, требующую большой затраты энергии и сил: ср. рус. «пенсионер Юля» (Издевались. Не брали в расчет. Все, «пенсионер Юля». Доживает последние деньки в политике [ВП, 19.06.2018]). При этом наблюдаем употребление разговорной 
формы имени Юля, а не официальной Юлия, что также служит иллюстрацией сниженной речевой тональности, снисходительного отношения.

В соответствии с принципом андроцентризма медиаобраз Юлии Тимошенко создается при помощи сравнения с мужскими образами, политическими деятелями, в частности и идеологами фашизма, например: рус. любимый «фюрер» (Нация фактически была оккупирована ставленниками Тимошенко. И все они, как один, предали своего любимого “фюрера» [ВП, 19.06.2018]); историческими деятелями, полководцами, которые стремились покорить весь мир, однако они, хоть и прославились, но вошли в народную память в негативном контексте, отличаясь отрицательными чертами характера, в частности такими, как амбициозность, честолюбие, эгоизм, желание славы любой ценой, жестокость и др., ср.: укр. Наполеон у спідниці від Айни Гасе без армії (Пані Юля - це Наполеон у спідниці від Айни Гасе без армӥ [УМ, 14.05.05]); или сравнение с Виктором Януковичем - экс-президентом Украины, олигархом, предательски сбежавшим в Россию после украинской Революции Достоинства и обокравшим государственную казну Украины, ср.: укр. новый Янукович (Висловлено підозру, що Тимошенко для Украӥни - новий Янукович [ДТ, 31.03.2014]). Подобные «мужские» метафоры-перифразы - свидетельство патриархального мышления, ибо мужчина всегда лучше женщины: он умнее, сильнее, качественно лучше. Но в случае Юлии Тимошенко сравнение с мужчиной свидетельствует о наличии у женщины-политика отрицательных черт, присущих тем мужчинам, с чьими именами сравнивается Юлия Тимошенко.

Ироническое шутливое метафорическое выражение рус. герой шуток про «простого украинца» - вербальная реакция на фотографию, где Юлия Тимошенко пьет кофе на автозаправке. Ср. контекст: Юлия Тимошенко выпила кофе на заправке и стала героем шуток про «простого украинца» [НВ, 23.10.2018]. Фразеологическую инновацию простой украинец употребляют в случае, когда необходимо представить обыденную ситуацию, но эта ситуация фальшивая, фейковая, не соответствует действительности; ср. также рус. списанный игрок - 'о Юлии Тимошенко в качестве кандидата на пост Президента Украины в 2014 году', ср.: После разгромного поражения Юлии Тимошенко на выборах Президента 2014 года и неудачном 
выступлении на выборах в Раду, многие считали ее списаннъьм игроком [Ц, 07.08.2018]; укр. гробар Помаранчевої революції (Тимошенко - әробар Помаранчевої революцйі [УМ, 31.07.2014]); рус. рейтинговый политик Украины ([...] самый рейтинговый политик Украины после отсидки в Харьковской больнице железнодорожников превратился в изгоя с плохо прокраичеными корняли волос [ВП, 19.06.2018]) и др.

Распространены метафоры-перифразы - сложные слова с приложениями, ср.: рус. политик-тяжеловес (Шансов в 2014 году у ослабленной Тимошенко практически не было, поэтому в президентских выборах она приняла участие исключительно ради того, чтобы о ней не забывали, как о возможном кандидате, политике-тяжеловесе и лидере политической силы [Ц, 04.07.2018]); рус. президент-оборотень (На Украине может появиться президент-оборотень [СП, 06.12.2018]).

Исследуемый материал показывает, что чаще моделируются иронические смыслы, ср.: укр. «душа Майдану» («душа Майдану» [...] наполягала [...] [УМ, 04.02.2001]). Также наблюдаем распространенный прием создания метафоры-перифразы на основании «присвоения высокого псевдотитула»: это свидетельствует о том, что их носители, а речь идет о Юлии Тимошенко, обладают не только неограниченной властью, силой влияния, цинизмом, коварством, но и привлекательностью. Чаще всего используются слова королева, принцесса, мадонна, ср.: рус. «газовая принцесса» (То ли, действительно, надоела местным толстосумам «газовая принцесса», то ли не поделили власть [Ц., 02.11.2018]); рус. «оранжевая принцесса» (До этого «оранжсевая принцесса» потребовала от России возместить все убытки, нанесенные Украине и ее гражданам в результате военных действий на юго-востоке страны и заявила, что Москва «заплатит сполна за агрессию» [Д., 06.11.2018]); укр. «газова принцеса» (Це у нас молода гарна жінка, «газова принцеса» [...] [УМ, 24-04.02.2005]; укр. лицемірна «принцеса» ([...] воліючи зректися «коренів», лицемірна «прицеса» цинічно змінила своє по батькові [...] [УМ, 02.04.2008]); укр. «кровожерлива принцеса» ( I ось що вийило: «кровожерлива принцеса» [...] [УМ, 02.04.2008]); укр. «помаранчева принцеса», «королева революции» (У ході Помаранчевої революцї ї̈ номінували «помаранче- 
вою принцесою», «королевою революциї» [...] ц̧і слогани вдало запущені [УМ, 02.04.2008;]).

Иногда, как видим, прилагательные-эпитеты, сочетающиеся с метафорой, имеют резко выраженную отрицательную оценку (кровожерлива, лицемірна), либо указывают на отношение к деятельности, которой занималась Юлия Тимошенко, например, газовая (принцесса): известно, что в свое время Юлия Тимошенко подписала не совсем выгодный контракт с Россией относительно поставки газа в Украину.

В процессе создания метафор актуализируются различные стилистические параметры, например: грубо: рус. «баба Юля» ([...] единственный, кто сможет этому «замечательному» плану помешать, это «баба Юля» [А, 08.10.2018]); пренебрежительно: рус. политиканша, не помнящая прошлого (Политиканиа, не помнящая прошлого, пытается развалить страну [Д, 16.11.2018]); иутливо-иронически: укр. «богиня Помаранчевої революції) («Богиня помаранчевої революциї» [...] наполягала саме на призначенні деяких заплямованих надто палкою співпращею з режимом Кучми кадрів [УМ, 24-04.02.2005]).

Редко, но все же моделируются и положительные смысловые оттенки, ср.: рус. фаворит президентской гонки - это слова известного олигарха Игоря Коломойского о Юлии Тимошенко, которая в апреле 2019 г. претендовала на пост Президента Украины. Употреблено в названии статьи: «Она уже во втором туре»: Коломойский назвал Тимошенко фаворитом президентской гонки [Ц, 21.11.2018]; рус. мастер необычных политических решений (Тимошенко - вообще мастер необъчных политических решений [ФАН, 07.02.2017]); укр. атомна електростанція (Юля - це атомна електростанція [СП, 24-30.03.2016]); укр. великий комп'ютер (Юля - це великий комп'ютер [УМ, 2404.02.2005]). При этом женщину-политика называют просто по имени.

Иногда прослеживаем моделирование языковой игры, что происходит, как отмечалось, в процессе актуализации явления прецедентности. Так, известный журналист Аркадий Бабченко сконструировал креативную номинацию-метафору рус. политиканша, не помнящая родства, актуализировав идиоматическое выражение Иван, не помнящий родства - 'о безродном 
человеке'. Ср. контекст: Политиканиа, не помнящая проилого, пытается развалить страну [Д, 16.11.2018]; ср. также рус. Белая Дама ([...] Несмотря на «изношенность» бренда Белой Дамъ в то, уже далекое время, ее политическая сила все же попала в парламент с довольно неплохим результатом [Ц., 04.07.2018]. В военном жаргоне белая дама обозначает 'холодное оружие' 34 : очевидно, эта метафора подчеркивает не только остроту слова политического лидера, но и ее коварность. Кроме этого, Юлию Тимошенко так называли, видимо, еще и потому, что она любит наряды белого цвета и является блондинкой, а еще символом ее партии было красное сердце на белом фоне (белый цвет - символ чистоты). В выражении белая дама сталкивается, как видим, несколько смыслов и также прослеживаем языковую игру. Используется прием капитализации, т.к. каждое слово в этом словосочетании написано с большой буквы вопреки правилам орфографии.

Женщина с косой - так иронически называют Юлию Тимошенко, для которой характерна прическа с уложенной вокруг головы косой. Однако и в этом случае возникает языковая игра, ибо актуализируется фразеологизм-эвфемизм: женщина с косой - так называют и смерть. Сталкиваются два смысла, при этом агрессия представлена эвфемистически. Ср. контекст: Женшина с косой нежно берет Донбасс за горло [СП.,19.07.2018]. Выразительность текста усиливается за счет его насыщенности фразеологизмами: женщина с косой и брать за горло. В украинском газетном дискурсе прослеживаем вариант «дама з косою» (3 Парижа вона привезла [...] цілу низку епітетів, якими украӥнського прем'єра нагородила французька преса - «слов'янська мадонна» [...] «дама з косою» [УМ, 24-04.02.2005]), но здесь моделируются метафоры-перифразы с положительным оценочным смыслом.

Актуализирован и негативный образ, связанный с азартными играми: «Чирвова королева» (Від «помаранчевої принцеси» до «Чирвової королеви» (название статьи) [УП, 22.01.2010]). Прецедентность этого выражения объясняется тем, что карты считаются атрибутами развлечений, а азарт, с которым сопровождается игра, алкоголь, и последующие «приключения», служат

${ }^{34}$ См.: Исторический словарь галлицизмов русского языка, https:/gallicismes.academic.ru/12130/\%Do\%B4\%Do\%Bo\%Do\%BC\%Do\%Bo\#sel=> cit. (2019.02.20). 
причиной порицания и запрета этой настольной игры в некоторых слоях общества. Дама червей считается покровительницей преступного мира.

Наблюдаем прием использования собственных имен известных лиц вследствие актуализации собственного имени в аббревиатурной форме, например, номинация леди Ди касалась британской принцессы Дианы, которую очень любили англичане. На основании названной номинации образовалась другая (образная) - «Леди Ю» как перифразированное имя Юлии Тимошенко, которое, казалось бы, должно положительно ее характеризовать по аналогии. Однако кавычки свидетельствуют о наличии иронии, ср.: [...] Тимошенко дышит в спину комик Зеленский (13 \% y «леди Ю» против 8 \% шоумена) [СП, 10.10.2018].

Прокомментируем еще один яркий пример: рус. «украинская Меркель». Метафора основана на сравнении украинского политика Юлии Тимошенко с Канцлером Германии Ангелой Меркель. Актуализирована ирония, ср.: Себя Тимошенко, естественно, видит «украинской Меркель», занимающей должность канилера нации четыре срока подряд [ВП, 19.06.2018]. Здесь имеет место распространенная модель: «имя известного деятеля + указание на этническую принадлежность, связанную с другим лицом». В примере канцлер нации также происходит сравнение Юлии Тимошенко с Канцлером Германии Ангелой Меркель, но собственное имя не называется, а имеется указание на должность в правительстве, распространенную исключительно в Германии, поэтому ситуация сравнения и понятна. Употреблено в названии статьи: Новый канцлер нации [...] [ВП, 19.06.2018].

Неоднократно прослеживаем использование прецедентных ситуаций. Так, в метафорическом выражении «оранжевая принцесса» речь идет о Юлии Тимошенко, которая во время Оранжевой революции в 2004 г. вместе с Виктором Ющенко боролась за справедливые выборы в Украине, ср.: До этого «оранжевая принцесса» потребовала от России возместить все убытки, нанесенные Украине и ее гражданам в результате военных действий на юго-востоке страны и заявила, что Москва «оплатит сполна за агрессию» [Д, 06.11.2018]. Прилагательное оранжевый получило статус прецедентного. Имеет место также посыл к имени Жанны Д'Арк для моделирования иронии (укр. В каземат - Тимошенкова Юлія, з каземату жанна Д'Арк [ЛУ, 27.01.2005]). На прецедентности построены 
и следующие метафорические образования, актуализирующие перифрастические номинации, в частности выражение «железная леди», впервые употребленное относительно премьерминистра Великобритании Маргарет Тэтчер, которая была первой женщиной в Европе, избранной на эту должность. Идиома железная леди употреблялась и относительно ряда других женщин-политиков, среди них Индира Ганди, Голда Меир. Однако наиболее последовательно эта номинация (англ. the Iron Lady) ассоциируется с Маргарет Тэтчер, известной жесткостью и бескомпромиссностью своей политики; она применялось к ней, прежде всего, в советских СМИ того времени - 70-80-е гг. XX века $^{35}$. Сегодня выражение «железная леди» используется в отношении женщин, занимающих высокие руководящие посты в бизнесе и на государственной службе. Такие женщины характеризуются непреклонным характером и жестким стилем руководства. Вполне логично этот фразеологизм употребляют и относительно Юлии Тимошенко: (укр. «залізна леді» (...деколи навіть видається, що «залізна леді» лягає із заплетеними косами спати, бо от уже кілька років ї̈ зачіска не міняється [УМ, 02.02.2005]).

Удачной представляется метафора, основанная на сравнении Юлии Тимошенко с княгиней Киевской Руси Ольгой, прославившейся тем, что она сумела жестоко отомстить за смерть своего мужа Игоря, т.е. княгиня отличалась силой духа, самообладанием, «мужским» характером, большой жесткостью. Данная метафора основана на прецедентном имени украинской истории, ср. укр.: рівноапостольна княгиня Олъга [...] [День, 25.11.2011]).

A пример училка категории MILF указывает на метафору, очерчивающую новый имидж Юлии Тимошенко после ее освобождения из тюрьмы. Аббревиатура MILF переводится, как 'мама, с которой я хотел бы заняться сексом', ср. контекст: Появился новый имидж-училка категории MILF в очках с распущенными волосами из классических немецких фильмов с разносчиками пиццы и сантехниками [ВП, 19.06.2018]. Это выражение имеет эвфемистический характер вследствие использования иноязычной аббревиатуры.

Популярными являются и зоометафоры с негативным значением, ср.: укр. біла тигриця (Для білої тигриці закон

35 И. И. Санжаревский, Политическая наука: Словарь-справочник, 2010, http://niv.ru/doc/dictionary/politicalscience/index.htm\#198 (2019-02-20). 
не писаний [УП, 04.01.2010]); лиса [лисиця - Т. К.] драна (Лідер Радикальної партї̈ Олег Ляшко хоче позбавити громадянства очільнищю фракцї̈ «Батьківщина» та називае ї̈ «лисою драною» [УП, 22.07.2016]), укр. кремлівська «зозуля» (Кремлівсъка «зозуля», яка з вдячністю за закриті в Росіӥ кримінальні справи виштовхувала з політичного поля проукраӥнських «помаранчових політиків» [УМ, 31.06.2014]); укр. московська зозуля (употреблено в названии статьи [ГП, 16.04.2016]).

Но наиболее оригинальным является метафорический образ «Юля-феникс», основанный на актуализации мифонима. Как известно, феникс - 'птица, обладающая способностью сжигать себя и возрождаться из пепла, символ вечного обновления’. В газетном дискурсе на основании прецедентного феномена создан иронический смысл, ср.: Там теперь в ходу шутки про «Юлю-феникса», которая в огне не горит и в воде не тонет [РЫ,14.12.2018]).

В проанализированном материале всего 5 примеров использования феминной метафоры антропонима Юлия Тимошенко в заголовках, однако в одном примере сталкиваются даже две метафоры, ср.: Від «помаранчевої принцеси» до «Чирвової королеви». В русскоязычном тексте, как и в украинскоязычном, прослеживаем также 2 метафорических употребления в сильной позиции заголовка. Подобные метафорические заголовки определяют как заголовки-экспрессивы; подчеркивается, что их компонентамим обязательно являются оценочность, эмоциональность и образность, иногда, как в вышеприведенном примере, проявляется контрастность, неожиданность переносного значения.

Среди собранных примеров, как отмечалось в процессе описания материала, большинство антропонимных метафор репрезентируют отрицательные смыслы, что целиком оправдано: негатив привлекает больше, а позитив воспринимается как норма. Примеры, представляющие положительные смыслы, составляют всего 3 \% от общего количества единиц собранной картотеки.

\section{выводы}

В исследованиях XXI века метафора изучается в пределах самостоятельного направления - лингвистической метафорологии 
и рассматривается как универсальное явление в гетерогенных измерениях на фоне интеграционных процессов научного, образного, ассоциативного, бытового, религиозного и других видов человеческого мышления. Она обладает специфическими возможностями онтологически воплощать в себе всевозможные сферы бытия: реальные, трансцендентные, интенциональные и т.д. Метафора - регулярное и продуктивное явление речи, фиксируемое в языке, с ярко выраженной антропоцентрической направленностью: человек рассматривается сквозь призму метафоры как объект, а не субъект познания. Креативные языковые личности видят источник метафорообразования в особенностях человеческого сознания - мировосприятия, миропонимания, мироощущения, пытаются осмыслить речевые процессы, касаясь мета-, экстралингвистической сферы. За каждой метафорой стоит еgо языковой личности.

Газетный дискурс, без сомнения, ярко и последовательно репрезентирует политическую сферу нашей жизни. Средства массовой информации справедливо называют «четвертой властью». Их основными функциями являются: 1) пропаганда, 2) агитация, 3) информация о важнейших событиях, происходящих в мире, 4) оценка, квалификация явления, освещение объекта в нужном свете, навязывание имиджа, не всегда реалистически, иногда включая «черный пиар», распространяя фейк, актуализируя «язык ненависти». При этом создаются и положительные, и отрицательные медиаобразы. Последние однако превалируют.

Читателей привлекает образная газетная речь, насыщенная стилистическими фигурами и тропами, яркими средствами экспрессии, эмоциональности, оценочности, среди которых и феминная метафора, ибо активная общественная позиция женщины находится сегодня в центре внимания журналистов. Публицистический дискурс последовательно отражает события, происходящие в обществе, иллюстрируя широкие возможности для создания и феминных метафорических образов с актуализацией перифразы, «накладывающейся» на метафору, что создает и языковую игру, моделирует оценку, иронические смыслы. При этом журналисты умело манипулируют феноменом прецедентности, создавая емкие метафорические комплексы.

Метафоры, основанные на актуализации собственного имени женщины-политика Юлии Тимошенко, как показал проанали- 
зированный материал, особенно выразительны и популярны: с одной стороны, они отражают андроцентризм, сексизм, но, с другой стороны, наблюдаем и новое явление - оригинальную вербализацию феминности: сравнение лица женского пола с другими известными женщинами, восхищение женским характером или осуждение его. Таким образом, современная феминная метафора - крайне неординарное явление в контексте лингвокультурного дискурса. Феминные метафоры - генераторы новых семантических коннотаций, образных смыслов, они являются не только способом познания мира, но и трансформируют новые знания, отражают этнокультурные традиции.

Для номинации Юлии Тимошенко используются традиционные модели: ее сравнивают с известными деятелями политики, историческими личностями, персонажами художественной литературы, ей присваивают высокие титулы и т.д. При этом используются яркие «говорящие» антропонимы. В современном русско- и украинскоязычном дискурсе сформировался медиаобраз Юлии Тимошенко как честолюбивого, амбициозного, властного, влиятельного, сильного, жестокого и жесткого, коварного политика, с мужским характером, но гибкого, мужественного, смелого, любой ценой достигающего цели, хитрого, умного, компетентного, эрудированного, элегантного, красноречивого, женственного, нежного, однако вследствие своей политической деятельности не достигшего желаемого успеха и не принесшего положительных результатов своей стране; политического лидера, у которого в Украине уже нет будущего, но продолжающего стремиться к власти. Антропонимы Юлия Тимошенко, Юля, безусловно, превратились в прецедентные имена, которые в будущем также будут использовать в качестве метафор, перифраз, имеющих емкое смысловое содержание.

Итак, феминная метафора газетного дискурса - мощный механизм моделирования медиаобраза, создания определенного имиджа личности, прежде всего, имиджа политического деятеля, который формируется на основе идентифицирующих языковых метафорических констант. 


\section{REFERENCES}

Andrienko, Liliya. Geneza ta osoblivosti strukturi metafori baroko: dis. ... kand. filol. nauk, Kï̈v, 1997 [Андрієнко, Лілія. Генеза та особливості структури метафори бароко: дис. ... канд. філол. наук, Київ, 1997].

Arkhangel'skaya, Alla. Seksizm v yazyke: mify i real'nost'. Olomouc: Univerzita Palachego, 2011 [Архангельская, Алла. Сексизм в языке: мифы и реальность. Olomouc: Univerzita Palachego, 2011].

Artemova, Lyudmila. Osobennosti funktsionirovaniya antroponimov $v$ nemetskikh mediynykh tekstakh [Артемова, Людмила. Особенности функционирования антропонимов в немецких медийных текстах] <http://www.dissercat. com/content/osobennosti-funktsionirovaniya-antroponimov-v-nemetskikhmediinykh-tekstakh\#ixzz2ugEVcH8o>.

Arutyunova, Nina. "Metafora i diskurs." Nina Davidovna Arutyunova, Zhurinskaya Marina Andreevna (ed.). Teoriya metafory, Moskva: Progress, 1990: 11-32 [Арутюнова, Нина. “Метафора и дискурс.” Нина Давидовна Арутюнова, Марина Андреевна Журинская (ред.). Теория метафоры, Москва: Прогресс, 1990: 11-32].

Bańko, Mirosław. "Peryfrazy w naszym życiu." Poradnik Językowy" 2002, nr 9: $3-23$.

Belyavskaya, Yevgeniya. "Freym 'politik' v angloyazychnom biograficheskom diskurse (k metodike analiza).” Politicheskaya Lingvistika 2012, no. 2(40): 21-26 [Белявская, Евгения. “Фрейм «политик» в англоязычном биографическом дискурсе (к методике анализа)”. Политическая лингвистика 2012, по. 2(40): 21-26].

Denisova, Alla (Ed.). Slovar' gendernykh terminov. Moskva: Informatsiya KHKHI veka, 2002 [Денисова, Алла (ред.). Словарь гендерных терминов. Москва: Информация XXI века, 2002].

Devidson, Donal'd. "Chto oznachayut metafory." Arutyunova, Nina. Zhurinskaya, Marina Andreevna (eds.). Teoriya metafory. Moskva: Progress, 1990: 173193 [Дэвидсон, Дональд. “Что означают метафоры.” Арутюнова, Нина, Журинская, Марина Андреевна (ред.). Теория метафоры. Москва: Прогресс, 1990: 173-193].

Dobrosklonskaya, Tat'yana. Medialingvistika: sistemnyy podkhod $k$ izucheniyu yazyka SMI: sovremennaya angliyskaya mediaset'. Moskva: Flinta, 1999 [Добросклонская, Татьяна. Медиалингвистика: системный подход к изучению языка СМИ: современная английская медиасеть. Москва: Флинта, 1999].

Eshchenko, Tetyana. Tekstovo-antropotsentrichniy vimir metafori ukrä̈ns'kikh poyetiv 199o-kh. Kiïv: Akademvidav, 2018 [Ещенко, Тетяна. Текстовоантропоцентричний вимір метафори українських поетів 199о-х. Київ: Академвидав, 2018].

Gak, Vladimir. Yazykovyye preobrazovaniya. Moskva: Shkola "Yazyki russkoy kul'tury,” 1988 [Гак, Владимир. Языковые преобразования. Москва: Школа “Языки русской культуры,” 1988].

Gurevich, Semen. Nomer gazety. Moskva: Aspekt Press, 2002 [Гуревич, Семен. Номер газеты. Москва: Аспект Пресс, 2002]. 
Istoricheskiy slovar' gallitsizmov russkogo yazyka [Исторический словарь галлицизмов русского языка] <https://gallicismes.academic.ru/12130/\%Do \%B4\%Do\%Bo\%Do\%BC\%Do\%Bo\#sel=> 2019-02-20>.

Kolomiєts', Mikola, Regushevs'kiy, Evgen Semenovich. Korotkiy slovnik perifraz. Kiïv: Radyans'ka shkola, 1985 [Коломиєць, Микола, Регушевський, Евген. Короткий словник перифраз. Київ: Радянська школа, 1985].

Kosmeda, Tetyana. Aksiologichni aspekti pragmalingvistiki: formuvannya i rozvitok kategorï otsinki. L'viv: LNU im. I. Franka, 2000 [Космеда, Тетяна. Аксіологічні аспекти прагмалінгвістики: формування і розвиток категорї оцінки. Львів: ЛНУ ім. І. Франка, 200о].

Kosmeda, Tetyana, Karpenko, Nataliya, Osipova, Tetyana, Salionovich, Lyudmila, Khaliman, Oksana. Genderna lingvistika v Ukraïni: istoriya, teoretichni zasadi, diskursivna praktika. Kharkiv: KHNPU im. G. S. Skovorodi; Drogobich: Kolo, 2014 [Космеда, Тетяна, Карпенко, Наталія, Осіпова, Тетяна, Саліонович, Людмила, Халіман, Оксана. Гендерна лінгвістика в Украӥні: історія, теоретичні засади, дискурсивна практика. Харків: ХНПУ ім. Г.С. Сковороди; Дрогобич: Коло, 2014].

Kosmeda, Tetyana, Khaliman, Oksana. Movna gra v paradigmi interpretativnö̈ lingvistiki. Gramatika otsinki. Gramatichna igrema (teoretichne osmislennya diskursivnoï praktiki). Drogobich: Kolo, 2013 [Космеда, Тетяна Анатоліївна, Халіман, Оксана. Мовна гра в парадигмі інтерпретативної лінгвістики. Граматика оцінки. Граматична ігрема (теоретичне осмислення дискурсивної практики). Дрогобич: Коло, 2013].

Kosmeda, Tetyana. "Metafora suchasnoï publitsistiki: aktualizatsiya antroponimiv (na materiali ukraïns'koï ta rosiys'koï mov)." Naukoviyvisnik DDPU imeni I. Franka. Seriya "Filologichni nauki. Movoznavstvo." 2015, no. 3: 106122 [Космеда, Тетяна. "Метафора сучасної публіцистики: актуалізація антропонімів (на матеріалі української та російської мов)”. Науковий вісник ДДПУ імені І. Франка. Серія „Філологічні науки. Мовознавство.” 2015, № 3: 106-122].

Kosyl, Czesław. "Metaforyczne użycie nazw własnych.” Szymczak, Mieczysław. Z zagadnień wspótczesnego języka polskiego. Wrocław: Ossolineum, 1978.

Kovalevskaya, Yekaterina. "Metafora i sravneniye v publitsisticheskom tekste.”. Vestnik KGU im. N. A. Nekrasova, 2009, nо. 3: 80-85 [Ковалевская, Екатерина. “Метафора и сравнение в публицистическом тексте”. Вестник КГУ им. Н. А. Некрасова, 2009, по. 3: 80-85].

Lyutaya, Anna. Sovremennyy gazetnyy zagolovok: struktura, semantika,pragmatika: avtoref. d. dis. ... kand. filol. nauk. Volgograd 2008 [Лютая, Анна. Современный газетный заголовок: структура, семантика, прагматика: автореф. дис. ... канд. филол. наук. Волгоград 2008].

Petrova, Nataliya, Ratsiburskaya, Larisa. Yazyk sovremennykh SMI: sredstva rechevoy agressii. Moskva: Flinta: Nauka, 2011 [Петрова, Наталия, Рацибурская, Лариса. Язык современных СМИ: средства речевой агрессии. Москва: Флинта: Наука, 2011].

Piroga, Inna, Izotova, Larisa. "Metafora yak zasib stvorennya imidzhu politichnogo lidera v nimets'komovnomu mediadiskursi." Diskursologiya, semantika i pragmatika. Visnik KHNU im. V. N. Karazina. Inozemna filologiya, vip. 88, 2018: 35-42 [Пірога, Інна, Ізотова, Лариса. "Метафора як засіб створення іміджу політичного лідера в німецькомовному медіадискурсі.” Дискурсологія, 
семантика і прагматика. Вісник ХНУ ім. В. Н. Каразіна. Іноземна філологія, вип. 88, 2018: 35-42].

Ponomareva, Ol'ga. Verbalizatsiyapoliticheskogo imidzha $v$ rossiyskikh $i$ amerikanskikh sredstvakh massovoy informatsii: dis. ... kand. filol. nauk. Volgo$\operatorname{grad} 2008$ [Пономарева, Ольга. Вербализация политического имиджа в российских и американских средствах массовой информации: дис. ... канд. филол. наук. Волгоград 2008].

Romanova, Anastasiya, Romanova, Yekaterina, Voyevodkin, Nikolay. Imya sobstvennoye $v$ politike: yazyk vlasti I vlast' yazyka. Moskva: Liliya LTD, 2000 [Романова, Анастасия, Романова, Екатерина, Воеводкин, Николай. Имя собственное в политике: язык власти и власть языка. Москва: Лилия ЛТД, 2000].

Rutkowski, Mariusz. "Koncepcja opisu konotacji nazw własnych w 'Słowniku metafor i konotacji nazw'.” Poznańskie Studia Polonistyczne. Seria językoznawcza, t. 19 (39), z. 1, 2012: 141-148.

Rutkowski, Mariusz. Nazwy własne w strukturze metafory i metonimii. Proces deonimizacji. Onomastica" 2017, no. LXI/2: 91-104.

Safronova, Yelena. "Individual'nyye smysly metafory." Vestnik Altayskogo gosudarstvennogo agrarnogo universiteta. 20066 nо. 3: 114-119 [Сафронова, Елена. "Индивидуальные смыслы метафоры”. Вестник Алтайского государственного аграрного университета. 2006, по. 3: 114-119].

Sanzharevskiy, Igor'. Politicheskaya nauka: Slovar'-spravochnik [Санжаревский, Игорь. Политическая наука: Словарь-справочник. 2010]. <http://niv.ru/ doc/dictionary/politicalscience/index.htm\#198> cit.

Shilikhina, Kseniya. "Metafora i ironiya." Vestnik Voronezhskogo gosudarstvennogo universiteta, Seriya Lingvistika i mezhkul'turnaya kommunikatsiya. 2009, nо. 2: 39-42 [Шилихина, Ксения. “Метафора и ирония.” Вестник Воронежского государственного университета. Серия Лингвистика и межкультурная коммуникация. 2009, по. 2: 39-42].

Straś, Ewa. "Peryfrazy w środkach masowego przekazu (na materiale prasy polskiej i rosyjskiej).” Czerwiński, Piotr (red.), Konfrontacje języków słowiańskich na poziomie leksyki, stowotwórstwa i składni. Katowice: Wydawnictwo Uniwersytetu Śląskiego, 2001: 102-110.

Voychenko, Viktoriya. "Otrazheniye gendernykh stereotipov v yazyke i kul'ture." Vestnik Volgogradskogo gosudarstvennogo universiteta, seriya Yazykoznaniye, № 1 (9), 2009: 64-70 [Войченко, Виктория. “Отражение гендерных стереотиповвязыкеикультуре.” ВестникВолгоградскогогосударственного университета, серия Языкознание, № 1 (9), 2009: 64-70]. 


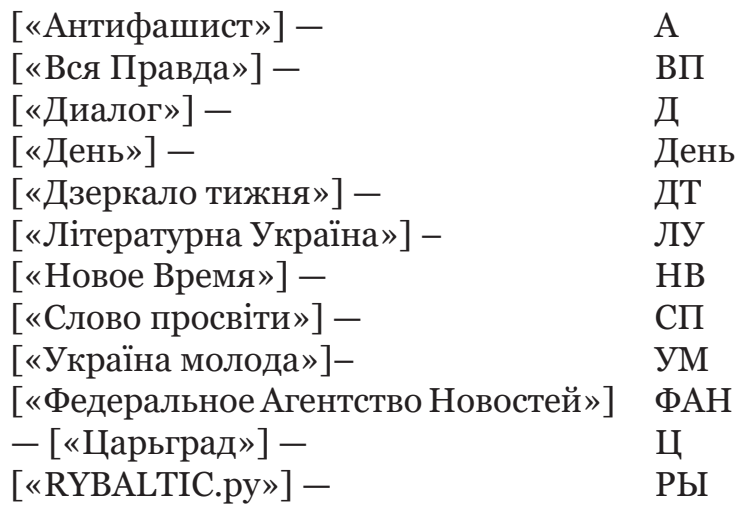

